January 2004

\title{
The Development of the World Trade Organization and the International Criminal Court
}

Sydney M. Cone III

New York Law School

Follow this and additional works at: https://digitalcommons.nyls.edu/nyls_law_review

Part of the Criminal Law Commons, International Law Commons, and the International Trade Law Commons

\section{Recommended Citation}

Sydney M. Cone III, The Development of the World Trade Organization and the International Criminal Court, 48 N.Y.L. SCH. L. REV. (2003-2004).

This Article is brought to you for free and open access by DigitalCommons@NYLS. It has been accepted for inclusion in NYLS Law Review by an authorized editor of DigitalCommons@NYLS. 


\title{
THE DEVELOPMENT OF THE WORLD TRADE ORGANIZATION AND THE INTERNATIONAL CRIMINAL COURT
}

\section{GUEST LECTURE AT THE OFFICE OF THE PROSECUTOR, INTERNATIONAL CRIMINAL COURT}

\author{
19 JANUARY 2004, THE HAGUE
}

SYDNEY M. CONE, III*

\section{A Look At The World Trade Organization}

In the context of the early stages of the International Criminal Court as a supranational institution, ${ }^{1}$ it may be instructive to look at an established multilateral juridical institution, particularly where a substantial body of history and jurisprudence is available for consideration, and above all where the other institution seems to have developed a supportive constituency in the international community. The World Trade Organization (WTO) is such an institution. ${ }^{2}$

While the types of crimes specified in the Rome Statute of the International Criminal Court ${ }^{3}$ are but infrequently related to issues that come before the WTO, both institutions share a common need to develop political and diplomatic skills that will help them to establish and maintain global credibility. The WTO deals with disputes involving mainly trade and (to a lesser extent) cross-border investment, and the cross-border licensing of intellectual property;

* C.V. Starr Professor of Law and Director, Center for International Law, New York Law School; Senior Counsel, Cleary, Gottlieb, Steen \& Hamilton.

1. For general materials see International Criminal Court: Questions and Answers, available at http://www.icc-cpi.int/php/show.php?id=faq (last visited Mar. 1, 2004).

2. Basic texts relating to the World Trade Organization (WTO) may be found at http://www.wto.org/english/docs_e/legal_e/legal_e.htm (last visited Mar. 1, 2004). They include the Agreement Establishing the World Trade Organization and, annexed thereto, a number of multilateral agreements on matters that include trade in goods (GATT 1994), trade in services (GATS), dispute settlement (the DSU), investment (TRIMS), intellectual property (TRIPS).

3. U.N. Doc. A/CONF.183/9 (1998) as corrected by later procès-verbaux; it entered into force on July 1, 2002 (hereinafter the Rome Statute). At present it grants the International Criminal Court jurisdiction over genocide, crimes against humanity, and war crimes. 
in other words, disputes in the realm of international economic law-as distinguished from criminal law. Also, the WTO deals with disputes between its member countries-as distinguished from prosecutions of individual criminal defendants. ${ }^{4}$ Arguably, the work of the WTO is less fraught with tensions than is the trial of persons accused of genocide or crimes against humanity or war crimes. Even so, the economic realm is rife with national jealousies and protectionist distrust of intermeddling by unelected international civil servants. ${ }^{5}$ The WTO thus may merit attention, because it seems to have been successful in developing the broad-based transnational acceptance manifesting, or at least not inconsistent with, the consensus that it needs in order successfully to handle difficult and seriously contested controversies in which substantial economic interests are at stake.

It was not always thus in the sphere of international trade. The WTO was painfully slow in coming into existence. The negotiation of the Agreement Establishing the World Trade Organization was every bit as tortuous-as plagued by crises, set-backs and deadlocks-as the negotiation of the Rome Statute. ${ }^{6}$ Indeed, if we go back to the negotiation and failed ratification of the Havana Charter-the Charter of the International Trade Organization-some 56 years ago, ${ }^{7}$ we can come to appreciate the range of talent and the qualities of character, including just plain patience, that go into creating an effective supranational tribunal.

In the beginning there was GATT, the General Agreement on Tariffs and Trade. Although its principal provisions and its great body of jurisprudence are still with us at the core of the WTO, it began modestly and it grew as a fragile enterprise beset with risk. Its long, incremental evolution took place at times in fits and starts, at times through organized rounds of negotiations. As originally conceived, the GATT was supposed to be administered by the Inter-

4. See generally The WTO Dispute Settlement Procedures (Aug. 1995) [hereinafter WTO Dispute Settlement Procedures].

5. Andreas F. Lowenfeld, International Economic Law 42-44 (Oxford Univ. Press 2002).

6. Compare id., at 61-67, with Human Rughts Watch, Myths and Facts about the International Criminal Court; and Questions and ANSWErs about the ICC AND THE UNITED STATES, both available at http://hrw.org/campaigns/icc/us.htm (last visited Mar. 1, 2004).

7. See LOWENFELD, supra note 5 , at 23-26. 
national Trade Organization; however, the ITO Charter was effectively rejected by the Government of the United States of America, among other countries-does this sound familiar?-and the ITO never came into existence. The GATT remained an orphan for almost half a century, until it was finally integrated into the WTO in January 1995. During its long orphanage, the GATT was a mere provisional agreement that was never ratified. Unlike the WTO today, the GATT was not a juridical entity. Institutionally, it was a staff based in Geneva for the purpose of administering the contractual GATT, a staff of international civil servants engaged by the countries called the contracting parties that had signed (but not ratified) this provisional agreement. ${ }^{8}$

The international civil servants who staffed this adventitious non-entity proved themselves to be very useful. They emphasized diplomacy. Indeed, for a long time-as it turned out, for too long a time-the GATT did not have a legal department. The contracting parties, aided by the staff in Geneva, developed what has been called "diplomats' jurisprudence." Terminology was importantand to this day remains important in the context of the WTO. At an early stage, disputes between contracting parties were referred to "working parties" for resolution, and they issued "reports" that made "recommendations." Thus, even when the proceedings had the effect of binding the disputing parties to a decision by a tribunal, crisp judicial terminology was avoided in favor of purposefully precatory diplomatic phraseology. In time, the "working parties" came to be called "panels," which is still the term for courts of first instance in the WTO dispute-settlement system. ${ }^{9}$

Of course, the analogy to the circumspection of the early GATT is not intended for literal application by the International Criminal Court in specific penal cases. The studied language of a "recommendation" deferentially addressed to a nation-state may not be susceptible of adaptation to a decision relating to an individual accused of a specific crime against humanity. Nevertheless, the analogy may still be apposite as a matter of general institutional culture, as a matter of appreciating the relationship to be devel-

8. See Robert E. Hudec, Enforcing International Trade Law, The Evolution of the Modern GATT Legal System 3-10 (Butterworth Legal Publ. 1993).

9. Id. at 11-15. 
oped between a supranational criminal court, on the one hand, and, on the other, the states that created it and on which it is altogether dependent. This dependency exists not only in operational areas such as obtaining evidence and carrying out sentences imposed on persons whom the court has found guilty, ${ }^{10}$ but also with regard to the fundamental necessity of building and retaining the confidence of the international community that the court is acting wisely and constructively in its administration of criminal justice.

The policy of the institutional GATT to conduct its juridical proceedings as exercises in diplomacy was modified when the absence of a legal department became an obvious and threatening problem. For many years, beginning in 1972, the staff of the institutional GATT had failed to deal competently with a controversy involving corporate income tax provisions that had been adopted by the United States and which certain European countries had claimed were illegal export subsidies under the relevant provisions of the contractual GATT. This failure ultimately persuaded the institutional GATT to add lawyers to its staff, a step that marked the turning of GATT dispute settlement into a process based on legal skills as well as diplomacy. ${ }^{11}$ The handling of the actual dispute was notable not only for giving rise to improvements in the way the institutional GATT functioned, but also for establishing an institutional commitment, through year after year of setbacks and frustrations, to adjudicating legal claims until they were eventually decided by resorting to precedent, legal analysis, and diplomacy.

The ups and downs of the GATT in the years preceding the WTO put to the test the development of a multilateral institution capable of resolving disputes. There was no master plan that had been laid out in advance. Unforeseeable problems arose, and at times individual governments responded to them in ways that were beyond multilateral control. The results were not always tidy but, overall, they produced a substantial body of case-by-case experience and a functioning, indeed, a valuable process for the settlement of disputes. The contracting parties and the staff in Geneva learned

10. On the role of States Parties as regards obtaining evidence and carrying out sentences, see the Rome Statute, supra note 3, at pts. 9-10.

11. See Hudec, supra note 8 , at ch. 5 ("The DISC [Domestic International Sales Corporation] Case"). 
to build an institution out of a quantity of routine cases, to survive major setbacks, and in the case of a bad result, to avoid paralysis and move on to the next problem. ${ }^{12}$

By means of a binding international agreement called the Understanding on Dispute Settlement, or DSU, ${ }^{13}$ the WTO disputesettlement system is expressly grounded in the jurisprudence developed under the institutional GATT. The DSU, which confers substantial judicial authority on organs of the WTO, was not separately submitted to the nations of the world for ratification. Rather, it was annexed to the Agreement Establishing the World Trade Organization, and the (to date) 148 countries that have ratified that agreement have, by the terms thereof, ipso facto ratified the documents annexed thereto, among them the DSU. As mentioned, courts of first instance under the DSU are called panels. Under the DSU, appeals of panel reports may be made to a tribunal which is called neither tribunal nor court-but has the bland name of Appellate Body. ${ }^{14}$ It has seven members. The blandness of its name belies its substantial power. Some writers on international law have called the Appellate Body the most powerful multilateral tribunal ever established. ${ }^{15}$

In theory, the Appellate Body and the panels are subordinate to the Dispute Settlement Body (DSB), comprising all 148 members of the WTO on a one-member-one-vote basis-not unlike the Assembly of States Parties to the Statute of Rome. A report by the Appellate Body, or a report by a panel which is not appealed, takes effect when it has been approved by the DSB. Under the DSU, the DSB must act no later than a fixed time on a report submitted to it, and the report is approved unless the members of the DSB unanimously disapprove it. Since the prevailing party in a dispute (as well as other countries supporting the prevailing party) is unlikely to disapprove a report favorable to it, the DSB is unlikely ever to disap-

12. See id. at $176-77$.

13. See WTO Dispute Settlement Procedures, supra note 4; see also supra text accompanying note 2 .

14. See WTO Dispute Settlement Procedures, supra note 4, at Art. 17.

15. See, e.g., LOWENFELD, supra note 5, at 150 ("The most complete system of international dispute resolution in history."). 
prove a report. For this reason, the Appellate Body, as a practical matter, is the court of last resort in the WTO system. ${ }^{16}$

The WTO generally, and the Appellate Body in particular, exist in a world of political danger, constantly called upon to take account of their vulnerability to hostile views inherent in domestic national politics. The discreet and adroit cultivation of domestic support and its counterparts-avoidance of gratuitous provocation, and gauging expressions of disaffection by various interests, governmental and non-governmental-are on-going aspects of building a supranational institution. It may be appropriate for scholars to comment on the power of the Appellate Body, but the Appellate Body itself might be well-advised to remember that, poorly managed, power can prove ephemeral.

Moreover, some problems do not get solved forever. The dispute mentioned above between the United States and certain European countries over export subsidies alleged to exist in U.S. corporate income tax law has resurfaced and involves very substantial sums of money. ${ }^{17}$ It is not the most tractable of problems, and the WTO may be called upon not only to provide legal rulings but also to help its two most powerful members, the United States and the European Union, to employ diplomacy in order to avoid major harm in the global arena.

Another problem that has confronted the WTO is the proper role of non-governmental organizations (NGOs) in dispute settlement. Industrialized nations have tended to favor the admissibility of briefs submitted by NGOs to WTO panels and the Appellate Body. Developing countries, on the other hand, have tended to view NGOs as unwelcome manifestations of the industrialized world, and have sought to exclude them from WTO dispute-settlement proceedings. ${ }^{18}$ It seems quite possible that the International

16. For a discussion of this process, see Sydney M. Cone, III, The Asbestos Case and Dispute Settlement In The World Trade Organization: The Uneasy Relationship Between Panels and The Appellate Body, 23 Mich. J. INT'L L. 103, 103-07 (2001).

17. Report of the Appellate Body, United States-Tax Treatment for "Foreign Sales Corporations," WT/DS108/AB/R (Feb. 24, 2000).

18. For a discussion of Non-Governmental Organizations and WTO dispute settlement, see Report of the Appellate Body, European Communities-Measures Affecting Asbestos and Asbestos-Containing Products, § III ("Preliminary Procedural Matter"), WT/ $\mathrm{DS} 135 / \mathrm{AB} / \mathrm{R}$ (Mar. 12, 2001). 
Criminal Court will not face this dilemma in similarly acute form, and will be able to involve NGOs constructively in its work.

\section{The National Security Exception}

In entering into an international agreement, nations commonly reserve the right to subordinate certain provisions of the agreement to a national-security exception, a right entitling each nation to place its national-security interests ahead of specified multilateral obligations. The exception in the GATT is quite broad; according to its Article XXI, nothing in that agreement is to prevent a contracting party from taking any action "which it considers necessary for the protection of its essential security interests." The national-security exception in the Rome Statute is much narrower; under its Articles 72 and 93, a State Party is entitled to invoke its national security as a ground for denying a request by the International Criminal Court for the production of documents or the disclosure of evidence.

Although the national-security exception in the Rome Statute is relatively narrow, it could in theory be used to inhibit the work of the Court rather seriously. In order to gather documents and other evidence, the agents of the Court are singularly dependent on obtaining the co-operation of the national criminal and law-enforcement authorities of the respective States Parties to the Statute. Of course, in the event of non-co-operation, the agents of the Court, through diplomacy or otherwise, may find practical solutions that would yield documents or evidence from sources that are helpful or at least not subject to crippling interference. Even so, the question might be asked whether there is a major practical risk that national authorities will withhold their assistance on grounds of national security.

An oblique answer to this question may be found by ascertaining what use nations have made of the broad national-security exception in the GATT over the long life of that agreement. Although it could have been feared that that exception would be invoked so frequently and so indiscriminately as to eviscerate the agreement itself, the history of the GATT reveals that its contracting parties and (more recently) the WTO member states have had recourse to the national-security exception but rarely, and only when 
there was at least a colorable argument that related to actual or threatened hostilities between states.

The Falklands/Malvinas conflict was one occasion when claims of national security were invoked under the GATT; the combatants and certain of their allies took this step in order, in effect, to supplement their shooting war with a trade war. One might question whether the war was of such gravity as to justify the suspension of obligations under the GATT by particular nations. ${ }^{19}$ In the event, the suspension was limited in time, and the countries involved elected not to parlay the suspension into a major controversy.

Another occasion when claims relating to national security were talked of in the context of the GATT was enactment by the United States of legislation known as the Helms-Burton Act, ${ }^{20}$ the purpose of which was to punish, or at least bring pressure to bear on, Cuba after its air force had shot down an aircraft identified with a dissident movement. For a while it looked as though U.S. trade and investment policy toward Cuba falling within the ambit of the WTO would seriously disrupt relations within the WTO. Threats were made but stopped short of irretrievable action. Time passed. The European Union, Canada and Mexico (that is, the aggrieved WTO members other than Cuba) allowed diplomacy to soften outraged calls for confrontation, and some of the more questionable provisions of Helms-Burton were kept in a state of suspension by the United States. In the end, the United States was forced neither to back down nor to invoke Article XXI of the GATT. ${ }^{21}$

If use of GATT's national-security exception can be taken as a guide, then the national-security exception in the Rome Statute may turn out to be a provision that, generally speaking, will not be abused. In addition, if there are times when abuse might be claimed, the GATT/WTO example suggests that a wise course of action might be to allow time for tempers to cool, and to seek not confrontation but a diplomatic solution.

19. See Raj Bhala, International Trade Law: Theory and Practice 601, 603 (2d ed. 2001).

20. Cuban Liberty And Democratic Solidarity (Libertad) Act Of 1996, 22 U.S.C. $\$ 6021$ (2004) [hereinafter Helms-Burton Act].

21. On threatened U.S. invocation of Art. XXI, see Nancy Dunne and Guy de Joncquières, US and EU set to resume Cuba talks, Fin. TIMES, Mar. 24, 1997, at 3. 


\section{The United States And “Aggressive Unilateralism"}

Beginning in 1988, that is, roughly during the period when the Uruguay Round negotiations were taking place but before it was known that they would result in the Agreement Establishing the World Trade Organization, the United States embarked on trade and trade-related policies that have been dubbed "aggressive unilateralism"22-a term that might (perhaps in a gesture of generosity) be applied to current United States policy in respect of the Rome Statute. As regards the multilateral agreements administered by the WTO, the United States, to a certain extent, has recognized that those agreements take priority over unilateral measures adopted by the United States in the pre-WTO years of U.S. "aggressive unilateralism." At best, "aggressive unilateralism" can be credited with having helped to promote the creation of the WTO. At worst, the United States does not seem indifferent to the goal of harmonizing its unilateral measures with the relevant multilateral agreements.

What, if anything, does the history of U.S. "aggressive unilateralism" presage for relations between the United States and the States Parties to the Rome Statute, not to mention the International Criminal Court itself? For the moment, no useful answer seems available to that question.

For what it may be worth, there is a development in U.S. private law that may prove relevant to crimes under the Court's jurisdiction-genocide, crimes against humanity, and war crimes. This development is found in certain cases in tort brought under the U.S. Alien Tort Claims Act. ${ }^{23}$ Only last month was the way cleared for claims under the Act to be heard by, and a definitive evaluation of these types of claims must await decisions by, the U.S. Supreme Court. ${ }^{24}$

The U.S. Alien Tort Claims Act was included in the first U.S. statute on the judiciary, enacted in 1789 , and confers upon U.S. federal district courts "original jurisdiction of any civil action by an

22. LOWENFELD, supra note 5, at 148-49.

23. 28 U.S.C. $\$ 1350$ (2003).

24. See Linda Greenhouse, Reviewing Foreigners' Use of Federal Courts, N.Y. TIMEs, Dec. 2, 2003, at A29. See also N.Y.L. ScH. CTR. INT'L. L., The International Review, Fall 2003, at 12. 
alien for a tort only, committed in violation of the law of nations or a treaty of the United States." Beginning with a decision by the U.S. Circuit Court of Appeals for the Second Circuit in 1980, case law has developed in the U.S. federal courts to the effect that "the law of nations" may include certain norms of public international law relating to genocide, crimes against humanity, and war crimes. ${ }^{25}$ As a result, if an "alien" (a person not a citizen or national of the United States) can establish tortious injury arising from a violation of the "law of nations" thus defined, the alien may be able to obtain redress in a private tort action in a U.S. federal district court.

To repeat, the U.S. Supreme Court has yet to issue a decision in this area. In addition, the decided cases have not established clear guidelines on when a corporate (as distinguished from an individual) defendant can be held liable under the Act, or the extent of complicity by a state that a plaintiff must show, or the extent to which a state may be immune from suit. The decided cases do indicate that the "law of nations" is to be construed strictly, and that a plaintiff has a substantial burden in establishing that a claimed norm of public international law is one a violation of which entitles the plaintiff to redress in an action in tort under the Act. Briefly put, under the court decisions to date, such a norm must be shown to be a universal, definable and obligatory norm in order for it to rise to the level of the "law of nations."

At the moment the most that can be said is that the U.S. Alien Tort Claims Act may prove relevant. The possibility exists that the International Criminal Court may see the development of some private court-made law in the United States that could bear on the Court's consideration of the crimes under its jurisdiction. Such a development, to the extent that it actually takes place, might give a new dimension to the term "aggressive unilateralism" as fostered in the United States.

IV. A Concluding Look At The Lodestone Of The Rule Of Law

Both the original GATT and the WTO were designed to bring the rule of law into areas of transnational economic endeavor

25. See, e.g., Flores v. S. Peru Copper Corp., 343 F.3d 140 (2d Cir. 2003). 
where, hitherto, there had been autarky, beggar-thy-neighbor policies, and the uncertainties attendant upon an absence of agreed multilateral standards to govern trade, (and, latterly) investment and the protection of intellectual property. Generally speaking, a consensus was attainable as to the need for or desirability of agreed multilateral standards. The substantive areas to be covered by them were more controversial, however; and, over time, as new areas were put forward for inclusion in the search for the rule of international economic law, the controversy tended to become more complex. Basically, there have been increasing tensions concerning the types and content of legal standards to be adopted as the classical views of industrialized nations have been challenged by (nations purporting to speak for) the developing world. ${ }^{26}$

Does one dare to be so bold as to look for useful lessons applicable to the rather different sphere of law under the jurisdiction of the International Criminal Court? Tentatively, two thoughts might be advanced. The first is that an international consensus may be within reach on the proposition that all legitimate spheres of human endeavor would greatly benefit to the extent that the multilateral rule of law, in the form of agreed, enforceable and enforced multilateral standards, were to be strengthened in a manner that would diminish recourse to criminal behavior. The second is that ipse dixit is unlikely to produce significant useful results; that much energy, resourcefulness and patience will have to go into the development of standards that will advance the cause of criminal justice and, at the same time, not run afoul of a multiplicity of political, social and economic agendas. The Court faces the daunting task of building a credible jurisprudence out of individual cases and, simultaneously, playing a major role in the never-ending task of transforming the Rome Statute into a relevant, living document.

It may be premature to discuss in a concrete fashion how the Court's legal and diplomatic skills will be applied. Even so, the creation by the Court's Prosecutor of a division responsible for jurisdiction, complementarity and international co-operation suggests

26. For general reading in this area, see Ruti Teitel, Transitional Justice (Oxford Univ. Press 2000); see also Ryan Goodman, International Human Rights Law in Practice, 2 Chi. J. Int'L L. 101 (2001); Guy Lesser, War Crime and Punishment, Harper's Magazine, Jan. 1, 2004, at 37. 
an early focus on developing and applying the Rome Statute's predicate provisions that recognize the complementary competence of the States Parties and the Court itself. ${ }^{27}$ Thus, in carrying out the Statute, the Prosecutor will need not only to weigh evidence that a prosecutable crime (genocide, a crime against humanity, a war crime) has occurred, but also to ascertain whether the authorities of the relevant States Parties are able and willing to prosecute. This double process may at times be interactive, and a determination as to criminal evidence may inform certain decisions as to the identity of the authority that will be responsible for prosecutorial action. This process (aptly adumbrated by the Prosecutor's administrative rubric of jurisdiction, complementarity and co-operation) can be expected to blend legal analysis with diplomatic interchange. To a certain degree, then, the GATT/WTO history discussed above may serve as helpful background material for policy-makers charged with enforcing the Rome Statute.

27. See generally The Office of the Prosecutor of the International Criminal Court, Informal expert paper: The principle of complementarity in practice (2003), available at http:// www.icc-cpi.int/otp/complementarity.pdf (last visited Mar. 1, 2004). 